\title{
ДИСЦИПЛІНАРНА ДІЛОВА ГРА У ВИВЧЕННІ ПРОБЛЕМ ВЧЕННЯ ПРО КРОВ
}

Р. Я. Кушнір

\author{
ДВНЗ “Тернопільський держкавний медичний університет імені І. Я. Горбачевського МОЗ Украӥни”
}

\section{DISCIPLINARY BUSINESS GAME IS IN STUDY DOCTRINE OF BLOOD}

\author{
R. Ya. Kushnir \\ SHEI "Ternopil State Medical University by I. Ya. Horbachevsky of MPH of Ukraine"
}

\begin{abstract}
Ділова гра містить у собі унікальні можливості для вирішення стратегії і тактики. На основі аналізу літературних джерел та досвіду автора висвітлено місце дисциплінарної ділової гри (зокрема, при вивченні проблем вчення про кров) в системі сучасної вищої медичної освіти. Розкрито підходи їі застосування в навчальному процесі шодо формування та розвитку знань.
\end{abstract}

Business game includes a unique opportunity to develop strategies and tactics. Basing on analysis of literature and own experience the role of the disciplinary business game (in particular, the study of problems the doctrine of blood) in modern higher medical education was highlighted. The approaches using of the business game in educational process to forming and knowledge development was exposed.

Вступ. Орієнтація процесу навчання у вищій школі на особистість студента та професійну модель його майбутньої спеціальності вимагає впровадження в практичну діяльність вузів більш інтенсивних технологій і методів. Ігрові форми й методи підготовки фахівців медичної сфери дозволяють не тільки оптимально враховувати професійні вимоги обраної студентами спеціальності, але й повністю засвоювати матеріал, розвивати професійну компетенцію. Ділова гра, в основу якої покладена комунікативна ситуація, містить у собі унікальні можливості для вироблення стратегії і тактики.

Основна частина. Вища освіта України, орієнтуючись на європейські стандарти і принципи Болонського процесу, потребує інноваційних технологій. Актуальною постає проблема розроблених педагогічних технологій і впровадження їх у навчальний процес [1-4].

Суть проблеми полягає в підготовці студентів до активної творчої діяльності на професійній ниві. Важливо, щоб уже під час навчання у вищій школі у студентів формувалися необхідні професійні знання, уміння та навички. Досвід підтверджує: цю проблему можна вирішити, власне, не за рахунок збільшення аудиторного навчання, а насамперед шляхом удосконалення організаційних форм навчальної роботи, використання й удосконалення в навчальному процесі активних методів навчання як головної складової інноваційних технологій [6].
Найбільш поширеними у вищій школі є пояснювально-інформаційні методи навчання, які полягають в організації засвоєння студентами готової інформації за допомогою різних засобів. В основу організації цих методів навчання покладений принцип передачі викладачем готових висновків науки. При застосуванні таких методів не виключається можливість пошукової діяльності студентів, однак передача готових висновків домінує. Студенти в основному заучують інформацію, тренуючи при цьому лише пам'ять. Але завчити - ще не означає знати. Уміння не можливо набути без активної практичної діяльності (розгляду конкретних ситуацій, рольових і ділових ігор тощо). Постає питання: як якомога швидше пристосувати студентів до особливостей обраної професії, виявити ті позитивні якості, які сприяють формуванню професійної творчої особистості. Активізація пізнавальної творчої діяльності студентів стимулює використання в навчальному процесі ділових ігор.

Ігрова діяльність людини являє собою складне і багатопланове утворення, яке має велике значення для життя і розвитку особистості. Для людини гра $€$ природною формою активності, що не тільки народжує гру, а й здатна свідомо і вільно виконувати вибір між грою та іншими видами діяльності. Саме у грі в розгорнутому вигляді вільно можуть бути реалізовані деякі психологічні особливості особистості.

Через гру людина накопичує найкращий свій досвід, бо грати - це те ж саме, що й експериментувати.

(C) Р. Я. Кушнір 
Будь-яка гра - це новий досвід, котрий, у свою чергу, стає джерелом нових знань, нових дій і нових ідей. Гра примушує людину напружувати свої сили у науковому пошуку, мистецтві та стимулює особистість до постійного самовдосконалення [5-7].

Сьогодні гра як один із найдавніших педагогічних засобів переживає нині період своєрідного розвитку: з успіхом застосовується як у шкільному, так і вузівському навчанні. Зростання інтересу до гри зумовлюється, з одного боку, розвитком педагогічної практики, а 3 другого - соціальними та економічними проблемами формування всебічно розвиненої, активної особистості.

Ділова гра застосовується для студентів, як правило, після проведеної лекції і має за мету закріплення викладеного на лекції матеріалу.

Така форма роботи (спочатку - лекція, потім ділова гра) дозволяє студенту не тільки засвоїти отриману інформацію, а й на практиці зіграти ту чи іншу ситуацію, самостійно вирішити всі питання, які в ній виникли.

Після закінчення кожної гри лектор разом із студентами аналізує правильність поведінки кожного 3 учасників гри, доповнює їх відповіді, надає корисні рекомендації щодо окремої ситуації.
Запровадження ділових ігор у навчальному процесі вирішує такі завдання: розвиває практичне мислення студентів, уміння аналізувати ситуацію, приймати конструктивні рішення.

Застосовуються такі технологічні форми та методи: - моделювання процесу праці;

- реалізація процесу “ланцюжок рішень”. Оскільки в діловій грі система, яка моделюється, розглядається як динамічна, це приводить до того, що гра не обмежується рішенням однієї задачі, а потребує “ланцюжка рішень". Рішення, яке приймається учасниками гри на першому етапі, діє на модель і змінює ії початковий стан. Зміна стану поступає в ігровий комплекс i на основі отриманої інформації учасники гри виробляють рішення на другому етапі гри і т. д.;

- розподіл ролей між учасниками гри;

- різниця рольової мети при виробленні рішень, які сприяють виникненню протиріч між учасниками, конфлікту інтересів;

- наявність керованої емоційної напруги;

- взаємодія учасників, які виконують ті чи інші ролі;

- наявність загальної ігрової мети у всього ігрового колективу;

- колективне вироблення рішень учасниками гри;

- наявність системи індивідуального або групового оцінювання діяльності учасників гри (рис. 1).

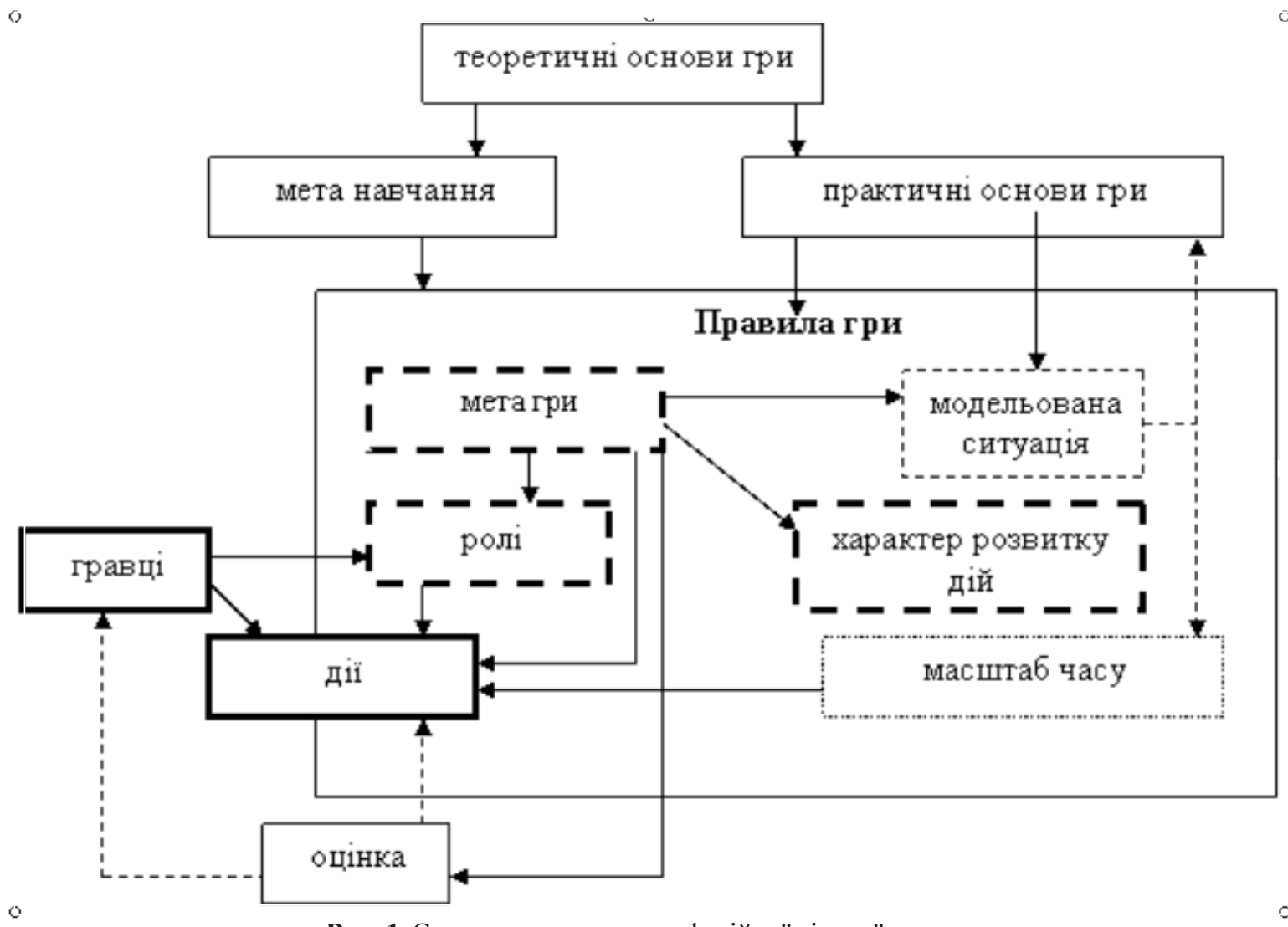

Рис. 1. Схема проведення професійної ділової гри. 
На занятті з трансфузіології було впроваджено такий методичний сценарій:

- Підготовчий етап: прочитана лекція "Вчення про кров. Групи крові та резус-фактор. Проби при переливанні крові”. Студенти самостійно опрацювали дані літератури, матеріали самопідготовки $[8,9]$.
- Основний етап:

1. На практичному занятті з даної теми викладач ставить питання: "При визначенні групи крові у хворого М. за допомогою стандартних еритроцитів отримано наступний результат:
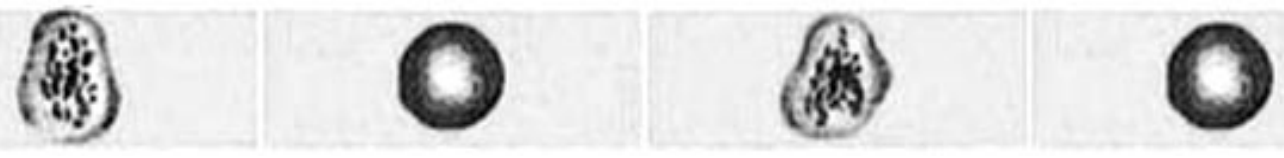

Запитання: “Яка група крові у пацієнта?"

2. Студенти групи діляться за спеціальностями: лікар-лаборант, завідувач клінічної лабораторії, бригада ургентних хірургів, завідувач хірургічного відділення, заступник головного лікаря з лікувальної роботи. Коротко знайомляться з функціональними обов'язками.

Запитання: "Які подальші дії кожного спеціаліста?"

3. Оскільки попередній результат є хибним, студенти визначають причини помилки та дії кожного спеціаліста для попередження ії̈ в подальшому.

Запитання: "Які можливі технічні помилки при визначенні груп крові? Які попереджувальні заходи слід використовувати для уникнення помилок?"

4. Студенти приступають до практичного визначення групи досліджуваної крові за допомогою стандартних сироваток та моноклональних антитіл.

Запитання: "Що таке титр сироватки? Які титри стандартних сироваток використовуються при визначенні груп крові? Які титри стандартних сироваток зазвичай використовуються при визначенні груп крові? Яке обладнання використовується для проведення визначення груп крові за стандартними сироватками? Що таке цоліклони? Які реагенти цоліклонів використовуються для визначення груп крові? Яке

Списоклітератури

1. Цехмістрова Г. С. Педагогічна майстерність та оцінка якості викладання у вищому закладі освіти / Г. С. Цехмістрова // Нові технології навчання. -2001. - Вип. 31. C. 24-33.

2. Івлєва А. Ділова гра / А. Івлєва // Навчально-методичний журнал “Освіта. Технікуми, коледжі”. -2011. - № 70.C. 30 .

3. Бабак М. І. Формування особистості медика третього тисячоліття / М. І. Бабак // Медична освіта. -2002. - № 1. C. $49-50$.

4. Василюк В. М. Основи клінічного мислення / В. М. Василюк, Н. В. Кравчук, В. В. Василюк // Медична освіта. - обладнання використовується для визначення груп крові за допомогою цоліклонів? Що таке перехресний метод визначення груп крові? Чи є необхідність використати перехресний метод визначення груп крові в даному випадку?"

- Заключний етап: підсумки і висновки ділової гри, розробка рекомендацій. Критеріями оцінювання служать компетентність, активність, швидкість у прийнятті правильних рішень у командній грі. Заключне слово викладача.

Висновки: 1. Ділова гра є засобом розвитку творчого професійного мислення, у процесі якої людина набуває здібностей аналізувати специфічні ситуації та вирішувати нові для себе професійні завдання.

2. Змістом ділових ігор є імітація умов певних ситуацій, їі динаміки, а також діяльність і взаємостосунки зайнятих у цьому особистостей; виконуючи вимоги гри, iii учасники приймають професійні норми спілкування.

3. Ділові ігри не тільки озброюють студентів результатами наукового пізнання, а й формують самостійність, розвивають та вдосконалюють здібності до творчої діяльності.

4. Участь у ділових іграх дозволяє оцінити реальний стан проблеми, а також отримати необхідну інформацію для прийняття правильних рішень.

2004. - № 3-4. - С. 33-36.

5. Мілерян В. С. Методичні основи підготовки та проведення навчальних занять в медичних вузах : методичний посібник / В. Є. Мілерян. - К. : Академвидав, 2006. - 352 с.

6. Пометун О. І. Інтерактивні методики та системи навчання / О. І. Пометун. -К., 2007. - 192 с.

7. Фібула М. М. Педагогіка вищої школи / М. М. Фібула. К. : Академвидав, 2006.-352 с.

8. Основи трансфузіології : підручник / [П. І. Лучанко, О. М. Кіт, І. В. Фрондзей та ін.]. - Тернопіль : ТДМУ, 2009. $-288 \mathrm{c}$.

9. Інструкція по визначенню груп крові за системами АB0, Резус та імунних антитіл. Наказ № 164 МОЗ України від 05.07.99. 